\title{
READING RADMILLA: THE SEMIOTICS OF SELF (BLACK AND
}

$$
\text { NAVAJO) }
$$

\section{Ricardo Guthrie}

Hearing Radmilla, a documentary film produced by Angela Webb in 2010, tells the powerful story of a Navajo/Diné woman, Radmilla Cody, from Leupp, Arizona, who wins the title of "Miss Navajo Nation" in 1997, and who later falls from grace as a result of an abusive relationship that lands her in prison. The film, developed between 1999 and 2010, depicts Radmilla's dramatic recovery, and illustrates how she uses her singing and speaking skills to counsel and inspire other women. The rise, fall, and rise again of Radmilla follows a lyrical narrative that is common in many sociocultural texts, particularly film. But, what is different about this narrative is that it includes the mythic arc of race and identity-Radmilla's father was African American, her mother is Diné, and she was raised on an Arizona reservation by her Navajo grandmother.

In this essay, I examine the semiotics of being Navajo and Black in a society and culture that problematically embraces and rejects aspects of indigeneity and Blackness. Hearing Radmilla proclaims the strength of self-ascribed "biracial" children who overcome the stigma of race and cultural identity in a racialised society which privileges racial purity-however one defines that-yet proclaims itself as being tolerant and accepting of a world "beyond race." The purpose of this essay is to examine the semiotics of self, race and gender, as depicted in the film. My goal is to "read" Radmilla-the filmic archetype of Indigeneity and Blackness-and to uncover "Millie" Cody, the "imperfect-perfect" human being who undergoes dramatic 
transformations while striving to strip away the stigma, hurts and injuries of race, gender and Indigeneity in an imperfect society.

\section{Evolution of the Self: Navajo and Black}

Craig Womack $(1999,2)$ states that, “[T]here are a number of realities that constitute Indian identity-rez, urban, full-blood, mixed-blood, language speakers, nonspeakers, gay, straight, and many other possibilities..." In this dramatic evocation of Radmilla Cody's phenomenal life, the filmmaker, Angela Webb, provides Radmilla a forum for articulating the power-and danger-of growing up "biracial" in America. To be sure, Radmilla's life on film is not a generic iteration of biracialism-it is a close examination of two of the most contested, and problematic, racialised groups: Native Americans and African Americans. ${ }^{1}$ First and foremost, Hearing Radmilla is a formidable evocation of what literary theorist Craig Womack describes as "Native perspective," and an "indigenous consciousness":

...there is such a thing as a Native perspective and ...seeking it out is a worthwhile endeavor. ... I feel that Native perspectives have to do with allowing Indian people to speak for themselves, that is to say, prioritizing Native voices. Those voices may vary in quality, but they rise out of a historical reality wherein Native people have been excluded from discourse concerning their own cultures, and Indian people must be, ultimately will be, heard. (Womack 1999, 4-5)

It is clear that Radmilla embraces a discourse that challenges static depictions of Nativeness, while seeking resolution between Blackness

\footnotetext{
${ }^{1}$ I will use Black and African American interchangeably, and I will use Native American, Navajo, Diné, and Indigenous as the context calls for it. In this approach to nomenclature, I am following other researchers, scholars and interpreters of race and popular culture, such as Kimberlé Crenshaw, Philip Deloria, and George Lipsitz. See, for example, Crenshaw "Race, Reform, and Retrenchment," Harvard Law Review, Vol. 101, no. 7, May 1988, 1332.
} 
and Indigeneity. The film, however, ultimately undermines her attempts to vocalise and embody an emergent identity that affirms both sides of her "biracial" experience. In addition, although she emerges as a spokesperson for women overcoming domestic violence and abuse, this aspect of the filmic discourse reifies her victimhood and raises more questions than it answers.

The filmmaker and editor combine plentiful images, sounds, and perspectives of Native American respondents, interviewees, and Radmilla herself, in articulating various dimensions of indigenous life in Arizona. Images of parades, the competition for Miss Navajo Nation, life on reservation ranches, photos from the Indian boarding school, and other depictions of Diné culture are all richly layered elements of the film that amplify Native perspectives. The perspectives are both enlightened and disturbing, as when Radmilla describes her feeling of vindication for winning the title, and the despair of reading letters from detractors printed in the Native press that she was "not really Navajo."2 Philip Deloria and other observers such as Sherman Alexie remind us, however, that both positive and negative perspectives about race are part of the indigenous experience. As Alexie stated:

Oh, yeah. I hear a hell of a lot more ni-er jokes on my rez than I did in the small farm town high school I went to. The thing is, it's all based on ignorance. There was one black person on the rez, and one in the farm town! (Talvi 1999)

\footnotetext{
2 "Miss Cody's appearance and physical characteristics are clearly black, and are thus representative of another race of people," wrote Orlando Tom, from Blue Gap, Arizona. “...[T] ribal members who are of mixed race are a threat to the future of the tribe," he added, even though Radmilla is fully enrolled and follows the matrilineal kinship of her Diné mother and grandmother. Quoted in Albuquerque Journal, March 1, 1998, A11.
} 
Radmilla notes that many supporters recognised her as a legitimate representative of Navajo culture, based on her matrilineal kinship, and being raised by her Navajo grandmother. Radmilla is of the Tl'aaschíi' (Red-Ochre-On Cheek) clan and is born for the African-Americans. Her grandmother was a stalwart defender of Radmilla's right to the title as the $46^{\text {th }}$ Miss Navajo Nation-she spoke the language, explained the culture, butchered a sheep and prepared a traditional Navajo dish, better than other contestants who were considered "fullblooded" Navajo/Diné. Both the grandmother and Radmilla contested the prevailing belief that Indigeneity is strictly a function of race, rather than kinship and cultural upbringing. Even knowledgeable observers elevated race above kinship: "You know, she's part-Black and part-Navajo...," remarked Marley Shebala, a Navajo Times journalist, expressing admiration that Radmilla outperformed other contestants. Ida Organich, Miss Navajo Nation (1953) gave a backhanded compliment: "The others were full-blooded Navajo, but Radmilla was good!"3

Radmilla, however, grew up in the same environment as other reservation inhabitants, and never met her African American father until she was a grown woman in her twenties. By traditional indigenous perspectives, kinship, and sovereign rights, Radmilla was,

\footnotetext{
${ }^{3}$ Celia Naylor provides an excellent discussion of the furor over Radmilla's selection as Miss Navajo Nation, examining newspaper commentaries, editorials, and responses, pro and con, over her racial and ethnic "authenticity" as a Native American. Naylor questions the debate over who may be accused of "playing Indian" (referencing Philip Deloria's historical framework for how "Americans" engage in racial ventriloquism to help suture together mythic, spiritual dimensions that can unify immigrants and ex-colonialists into a national grouping) and offers Cody's story as a cautionary tale over who ultimately determines what is "real" or authentic indigeneity. See Crossing Waters, Crossing Worlds: The African Diaspora in Indian Country, 2006, edited by Tiya Miles and Sharon P. Holland.
} 
and is, Navajo/Diné. But seen through the prism of race-her physical features, dark skin, full lips, etc.--she was considered "part Navajo."

Filmmaker Angela Webb effectively recounts the highs and lows of Radmilla's quest to represent the Navajo Nation, and provides interviews of other Miss Navajo winners who describe the lifelong challenges and notoriety that come with the title. Hearing Radmilla provides ample opportunities for Radmilla to be "heard," and she is an honest, courageous person for sharing her story. But there is a tension between Radmilla's performance of indigeneity on film (singing traditional songs arranged by her uncle, Herman Cody; speaking to native groups; and relating her cultural experience and upbringing as sources of strength), and the traumatic contestation over race and blackness that Radmilla/Millie endures.

Millie is a compelling storyteller whose different voices-Navajo daughter of mixed-race heritage; sheepherder and purveyor of Navajo language and culture; singer and performer of pop and traditional tunes; and representative of both the Navajo Nation and African America-are splendidly captured by documentary footage, interviews and interspersed photos, images, and newsclippings. Over the course of the film, however, the editing and use of such personal and observational revelations reinscribes Millie's voice and perspectives into a projection of trauma and triumph over violence and abuse by her boyfriend -who is revealed to be African American.

What begins as a personal saga of biracial identity discovery and transformation-being Navajo and Black in both traditional and nontraditional, rural and urban, settings-ends up as a problematic narrative of domestic abuse, Black deviance, imprisonment and atonement. There is no question that the story reflects Millie's voice and personal experience. The filmic encounters with Radmilla as competitor for Miss Navajo Nation-a blossoming indigenous 
ambassador, singer and performer of native and pop cultures, with heart wrenching descriptions of the impossible dilemma of having to testify against her boyfriend while perjuring herself, and the reaction to being incarcerated and then having to recover from two years in prison and revive her life and career afterwards-are all effectively conveyed.

What is problematic, however, are the segments of the story that speak louder than Radmilla: the binary of Navajo and Black is unbalanced and troubling-her idyllic life and trajectory as a young Diné recording artist and ambassador for the Navajo is interrupted by a dangerous detour after she falls in love and then tries to leave behind her "street smart" boyfriend in Phoenix. Rather than providing interviews with respondents who might be familiar with life in Phoenix and Black culture in general (recording artist Adina Howard and Millie's father, Troy Davis, are the only African Americans interviewed), viewers are left with the unmistakable impression that the worst thing to happen to Millie was to discover that being "Black" means suffering violence and abuse. In many ways, the story positions it as a "Whitney Houston" against "Bobby Brown" dynamic, and the end result is not pleasant.

By the end of the film, Radmilla takes responsibility for her fall from grace, and commits herself to counseling other young women against domestic abuse and towards confronting the stigma of being "Black" within Navajo culture. Both depictions are dramatic triumphs that are clear highpoints of her life; however, as the film allows Radmilla a chance to redeem and reinscribe what it means to be biracial and a survivor of domestic abuse, the film also inadvertently reinforces 
prevailing assumptions and presumptions of Black deviance and indigenous "otherness" that are still problematic. ${ }^{4}$

\section{“Dream on, Chocolate Mama!"}

Radmilla bears testimony to the difficulties of growing up Navajo and Black on an Arizona reservation. From her earliest arrival at her Navajo grandmother's ranch in Grand Falls (her mother, Margaret, was 18 when Millie was born, and the grandmother felt Margaret was not ready to care for a child), Radmilla was treated with curiosity, condescension and scorn. Her Uncle Rocky recalls being shocked that she was so dark: "What's this f-ing nigger baby? This ain't Detroit!" But Millie's father was not around to raise her-for reasons that are

\footnotetext{
${ }^{4}$ Sherman Alexie, in his poem, "How to Write the Great American Indian Novel," perhaps outlines a common theme that undergirds most of this filmic narrative: "All the Indians must have tragic features... The hero must be a half-breed... preferably from a horse culture... There must be redemption, of course, and sins must be forgiven..." This is one-half of the story retold by Radmilla. The other half, about the African American subculture, is weakly explored by the filmmaker. Millie's father, Troy Davis, enters her life after he learns she has won the Miss Navajo title in 1997. He admits that he wished he had been around to advise her and protect her from the "street smart" guy who became her boyfriend. No one else is interviewed to explore or explain the many perspectives of African Americans in U.S. society-how the "hidden transcript" of race bolsters the antiblack sentiments that pervade American culture. Despite W.E.B. Du Bois's theorisation that "the problem of the twentieth century is the problem of the color-line," by the time Millie came of age in the 1990s, discrepant images of blackness and African American culture were still dominant and in effect. The hegemonic discourse of black deviance, pathology, urban decline, and sexual attraction/repulsion are yet inscribed within this "documentary" film, as viewers are slowly introduced to boyfriend Darrell-street-smart Black hustler, violent abuser, who coerces Radmilla into running drugs for him. Although Millie survives to tell a triumphant story, the narrative that being Black is a curse from which she cannot escape remains unchallenged.
} 
not explained in the film-and Millie did not meet him until she was a grown woman who had already competed and won the title of "Miss Navajo Nation" in 1997.

Nevertheless, her uncles grew to love her, even as they taunted her about her Black heritage. "That's my cocoa-mama," Uncle Rocky proudly proclaims in the film, pausing to weep over the memory. And this, then, is perhaps the film's strongest aspect: capturing the comments and heartfelt reflections of those closest to Millie, including her uncles, her grandmother, her mother, friends, and commentators such as other Miss Navajo contestants, and journalist Marley Shebala. Shebala notes, "she was that perfect person, who was imperfect," discussing how Miss Navajo was not supposed to exhibit any flaws while representing the Nation.

The film "hears" Radmilla as she describes her bucolic, rural upbringing in traditional Navajo culture: raising sheep and goats, learning to grow crops and cook traditional foods, tell Navajo stories, and her early proclivity for music and singing. "I was Whitney Houston-singing to my sheep and nanny goats, out on the plains," she declares. "I would serve them cake and sing 'Happy Birthday'; they were my greatest audience!" Millie's early years on her grandmother's ranch were interrupted when she was sent to an Indian boarding school in Leupp, Arizona, where she was challenged to assimilate to American culture, along with the other indigenous students.

"I was taunted [for being Black and Navajo] as a kid," she said. "There's a word for 'Black' in Navajo: 'Zhini', which is synonymous for 'nigger'..." But, her grounding in Navajo culture ultimately provided a bridge between her and other Diné children during the boarding school years. She attended school in Leupp on and off from kindergarten to high school, before she enrolled in Coconino High in Flagstaff. She knew nothing about being African American, and had 
never heard of Martin Luther King or Malcolm X, testament to the restrictive boarding school environment, which belittled Black and indigenous culture and knowledge.

Boarding schools have been cruel training grounds for indigenous children throughout American history, and they embody the conquering logic of how Americans sought to "assimilate" Indian "Others" through cultural genocide. "We were punished for speaking Navajo," Radmilla recalls. So the children practiced speaking Navajo secretly among themselves. In this way, shuttling between Leupp and her grandmother's ranch, she developed an appreciation and understanding of two different worlds.

The institutionalising coercion of Indian boarding school was offset by real-world lessons in Diné culture, language, and tradition that were practiced and reinforced by the other children, and by her grandmother and uncles. Radmilla learned the strength, and the dangers, of being Navajo, Black, and living under a coercive institutional regime. She also met the reigning "Miss Navajo" at the Leupp boarding school, and imagined some day competing for the honor of representing all Diné/Navajo.

Her Uncle Rocky recalls: “She told me: 'Hey uncle, I'm gonna be that!' I told her: 'Dream on, Chocolate Mama!'” But before she could compete for Miss Navajo Nation, Radmilla left the reservation to enroll in college down in the big city-Phoenix, where she encountered another world that was attractive yet challenging in many ways. Her close friend, Adina Howard, recalls in the film: "That was Millie...like the Amish off the Rez" - fresh off the farm, and not ready for city life. "My curiosity led me to a lot of bad decisions," Millie remembers. 
At this point in the film, Webb asked her if she wanted to talk about her boyfriend. Millie paused, and began to tell the story of falling in love, living in the fast lane of cars, music, parties, and, ultimately, abuse. Her boyfriend sold cars, but also ran drugs; he coerced Millie to traffick drugs through the Phoenix airport for him. She was too scared to resist, and suffered violent abuse: "It started with a push, and escalated. I was black and blue from the beatings..."

Finally, she left Phoenix, returned to the reservation, began her singing career, and became Miss Navajo Nation from 1997-98. "I was not allowed to have a boyfriend, so I was away and had time to heal," she recalled. She was only 23 when she moved to Window Rock, and fought back against those who derided her mixed heritage.

Her singing was the blessing that became a bridge to others. "We have a lot of respect for singers," noted Marley Shebala."Our prayers are songs..." Radmilla released CDs in 2000 and 2001 with her uncle Herman. They were compilations of Navajo songs that featured unique instrumental accompaniments. She was the "queen of two cultures," according to newspaper clippings of the period, speaking to Black History Month audiences, and traveling around the state as a proud goodwill ambassador. Her evolution as a spokesperson for Navajo and as a performer was nearly complete; however, after finishing her term as Miss Navajo, she returned to her boyfriend, Darrell, who was increasingly jealous of her success as a singer and recording artist. "I still loved him," Millie said, even though she suffered more physical abuse and was ultimately called before a Grand Jury in Tulsa, Oklahoma, to testify about her knowledge of Darrell's drug operations.

Millie, AKA "Marilyn Kelly," was indicted and later convicted for withholding information about her own involvement in her boyfriend's drug running. Her attorney presented evidence that Millie 
was a victim of violent abuse and physical coercion, but the federal prosecutors and the judge discounted her testimony of abuse because she had not fully disclosed how she had transported drugs to and from the airport. Her sentence, after pleading guilty to "misprision of a felony," netted her 21 months in a federal prison camp. She began serving time in 2002 and, though it was prison, she said "It felt like boarding school...” in which she examined her life, her beliefs, and the actions that led to her imprisonment.

She was derided in newspapers for bringing disgrace to the Dine nation as a former Miss Navajo. Although it was a very difficult period for her, "It was a blessing - to be able to look at myself, and heal," she said. When Millie completed her sentence in July 2004, she was determined to talk to women on the reservation, and around the world, about surviving domestic violence. "A lot of people on the Rez were going through the same thing," Marley Shebala said. "But she was a role model," so she had to explain how even Miss Navajo was not immune to violence against women.

\section{Not Zhini ... but African American: “A Dark Calmness”}

Radmilla left prison and resumed her recording career, releasing albums in 2005 and 2006, and taking on another cause as well: "A medicine man told me of another word for African Americans: 'Na 'hii 'she'-meaning 'dark calmness, one-ness'... not Zhini, but a new word." Millie says part of her mission now is to teach a new understanding of African Americans to other Navajo children-and to combat prejudice against biracial people.

The narrative arc of the film concludes with her tearful "homecoming" speech, and an elaborately produced music video from her album. Radmilla/Millie is resurrected and whole-but the carefully constructed ending relies on a somewhat mythic evocation of 
reclaimed native performance. The slick editing and smooth video transitions between singing on the plains and sitting indoors before a mirror undermine the supposed transformation and release of this remarkable person. The music-video production underscores how performances of race and Indigeneity are often packaged and arranged for consumption by audiences and listeners who develop appetites for merged identities which can reinforce their expectations of what is good, valuable, or useful in American Indian culture. As Philip Deloria notes, the value of Indian culture evokes desire and revulsion, and production of "ethnic gifts" that can be used to affirm a (false) “American” pluralism:

Since the colonial era, Indian Others had been objects of both desire and repulsion, and in that raging contradiction lay their power. Now, they [are] almost completely flattened out, tragic victims who brought the last powerful remnants of their cultures as ethnic gifts for a pluralist American whole (Deloria 1998, 175).

Radmilla has a beautiful singing voice and a captivating presence on screen and in person, and to the Navajo/Diné she can be admired for advancing and popularising Navajo songs. She can also challenge Diné to be more accepting of "mixed-race" people who are part of the Navajo nation. To African Americans she can express levels of understanding about being Black in a white world. To non-Black and non-indigenous peoples she can represent all that is attractive, exotic, and yet problematic to the white world-gazing upon her rise, fall and rise again. The film bears witness to the effect of racism and violence against women, but it clumsily reduces Millie's personal triumphs into a polemic against domestic violence and black masculinity. When it might be a platform for better articulating emerging identities that exceed simple binaries of race or nation, it is lacking effective analyses or respondents who could comment on the tensions and lingering questions of the meaning of Navajo/Black identity. 
Radmilla proclaims her "biracial" heritage, but her explication-and her experience-is mostly as a "non-white" person whose traumatic journey fits standard tropes of the racialised "Other" who is attractive, desirable, but exoticised and ultimately scorned because the dominant world refuses to accept her as a multidimensional person. Her music video inscribes an acceptable performance of Indigeneity, even as she sings lyrics that exalt her journey of discovery beyond Native American themes. Further, the unexplored sign and signification of "Blackness" remains obscured by the damaging encounter with her convicted ex-boyfriend, drug kingpin Darrell, and the lingering questions about the loving, absent Black father. This type of "trauma drama"-in which viewers are invited to witness the violence and abuse inflicted on victims by African American males-may elicit a cathartic response by knowing survivors such as Radmilla/Millie; but more often the cathartic response reinforces misplaced beliefs that Black culture, and Black men, are best avoided, even by those who profess to love black culture.

Such narratives conform all too easily to established themes of racial subjugation that support the logic of continued white dominance over indigenous and African American peoples. Ultimately, to be biracialBlack and Navajo-only compels pity and charity, rather than empowering or liberating those who carry the mantle for both groups. It is the unintended consequence of the film that manufacturing an image of Radmilla performing legible identities occludes Millie's valiant evolution and transformation as a Navajo/African American, performer, and resilient counselor of abused women. The film relies upon a simplistic trope of an abused biracial woman (non-white), who is punished for her sins, yet emerges triumphant to tell a transformative story to other women and victims of Black violence and deviance. 
Millie's performance of indigeneity stabilises her identification but it is illegible and invisible to viewers about what it means to be Black, and desirable, in Navajo and non-Black environments. Radmilla has escaped the boarding school and the prison, but she remains incarcerated within the fictive imaginary of biracial identity formation that may yet emerge through the tensions of merged consciousness and experience. ${ }^{5}$ Hearing Radmilla says far less about Millie being heard, than about the tensions and conflicts of racialised identities with which she has wrestled throughout her life. It requires more forthright respondents from the African American perspective, or perhaps a deeper explication from Millie herself: her feelings, hopes and fears, written in her own words, and mined from the journals, diaries and letters that she wrote during her incarceration. She has grasped what it means to be Black and Navajo, and using the words of Leslie Marmon Silko, beckons all of us to join together as her sisters

\footnotetext{
${ }^{5}$ Jared Sexton evaluates the historical evolution of "mixed-race" identity movements in the United States, and declares that biracial peoples-even as they agitate for recognition as existing outside of a simple black/white binary-are trapped within a "white/non-white" racial prism because white dominance, and supremacy in sociocultural as well as political-economic domains, remains firmly in place. The "afterlife" of slavery, he maintains, has yet to allow non-white subjects to secure meaning and standing in American society. Thus, "biracial" peoples are still measured by how much (or how little) they resemble "whites" in phenotypical dimensions-regardless of their cultural affinity for the dominant culture. Native/indigenous, or non-white "others," who are "raced" with Blacks or other non-whites, do not exist as "biracial" others occupying a "third space or race," so much as they exist as "non-white" others jockeying for position between raced subjects whose identities, histories, and cultures are already being erased, appropriated, or reinscribed by the dominant culture. For these "others," physically escaping the ghetto, reservation, boarding schools, and prisons might be possible, while the narratives of deviance and subjugation follow them wherever they go. See Sexton, "People-of-Color-Blindness: Notes on the Afterlife of Slavery," Social Text 2010 28(2 103): 31-56.
} 
and brothers: "In the view of the old-time people, we are all sisters and brothers because the Mother Creator made all of us-all colors and all sizes. We are sisters and brothers, clanspeople of all living beings around us" (1996, 63-64).

\section{References}

Alexie, S. The Summer of Black Widows. Brooklyn: Hanging Loose Press, 1996.

Crenshaw, K. 'Race, Reform, and Retrenchment,' Harvard Law Review 101, 7 (1988): 1331-1387.

Deloria, P. J. Playing Indian. New Haven: Yale University Press, 1998.

Du Bois, W.E.B. The Souls of Black Folk. Boston: Bedford Books, 1997.

Guthrie, R. 'Oprah Winfrey and the Trauma Drama: 'What's So Good About Feeling Bad?' in Presenting Oprah Winfrey, Her Films, and African American Literature, edited by T. T. Green, 4578. New York: Palgrave, 2013.

Lipsitz, G. The Possessive Investment in Whiteness: How White People Profit from Identity Politics. rev. ed. Philadelphia: Temple University Press, 2006.

Lipsitz, G. Time Passages: Collective Memory and American Popular Culture, Minneapolis: University of Minnesota Press, 1990. Naylor, C. 'Playing Indian?' The Selection of Radmilla Cody as Miss Navajo Nation, 1997-1998.' In Crossing Waters, Crossing Worlds: The African Diaspora in Indian Country, edited by T. Miles and S. P. Holland, 145-163. Durham: Duke University Press, 2006.

New Yorker, 'Q \& A: Redeemers: Sherman Alexie Talks about His Native American Heritage...' The New Yorker Online, April 21, 2003: http://www.newyorker.com/archive/2003/04/21/030421on_o nlineonly01. Accessed May 6, 2013. 
Sexton, J. 'People-of-Color-Blindness: Notes on the Afterlife of Slavery.' Social Text 28 (2010): 31-56.

Silko, L. M. Yellow Woman and a Beauty of the Spirit. New York: Simon \& Schuster, 1996.

Talvi, S. 'Sherman Alexie Isn't Who You Think He Is.' COLORS NW Magazine, December 6, 2003.

Womack, C. Red on Red: Native American Literary Separatism, Minneapolis: University of Minnesota Press, 1999. 